\title{
Stranding survey as a framework to investigate rare cetacean records of the north and north-eastern Brazilian coasts
}

\author{
Alexandra Fernandes Costa',2, Salvatore Siciliano',3, Renata Emin-Lima', \\ Bruna Maria Lima Martins ${ }^{4}$, Maura Elisabeth Moraes Sousa ${ }^{1,5}$, \\ Tommaso Giarrizzo ${ }^{2,6}$, José de Sousa e Silva Júnior ${ }^{1}$
}

I Grupo de Estudos de Mamiferos Aquáticos da Amazônia (GEMAM). Programa de Capacitação Institucional, Setor de Mastozoologia, Coordenação de Zoologia, Museu Paraense Emílio Goeldi. Av. Perimetral, 1901, Terra Firme, 66077-530 Belém, PA, Brazil 2 PPG em Ecologia Aquática e Pesca, Universidade Federal do Pará-UFPA, Instituto de Ciências Biológicas, Cidade Universitária José da Silveira Netto, Av. Augusto Corrêa n 1, Guamá, 66075-110, Belém, PA, Brazil 3 Instituto Oswaldo Cruz/FIOCRUZ, Pavilhäo Mourisco - sala 122, Av. Brasil, 4365 - Manguinhos, 21040-360, Rio de Janeiro, RJ, Brazil 4 PPG em Ecologia e Conservação da Biodiversidade, Universidade Estadual de Santa Cruz - UESC. Rodovia Jorge Amado, km 16-Pav. Maz de Menezes, $1^{\circ}$ andar, sala 1DA, Salobrinho, 45662-900 Ilhéus, BA, Brazil 5 PPG em Biologia Ambiental, Universidade Federal do Pará - UFPA, Campus de Bragança. Alameda Leandro Ribeiro s/n, Aldeia, 68600O00 Bragança, PA, Brazil 6 Laboratório de Biologia Pesqueira e Manejo dos Recursos Aquáticos, Universidade Federal do Pará - UFPA, Av. Perimetral, 2651 Terra Firme, 66077-830 Belém, PA, Brazil

Corresponding author: Alexandra Fernandes Costa (alexandrafernandescosta@gmail.com)

Academic editor: P. Stoev | Received 9 March 2017 | Accepted 30 May 2017 | Published 9 August 2017

http://zoobank.org/D8F0CDB4-ADC4-487D-B9D4-12EA060A5324

Citation: Costa AF, Siciliano S, Emin-Lima R, Martins BML, Sousa MEM, Giarrizzo T, Silva Júnior JS (2017) Stranding survey as a framework to investigate rare cetacean records of the north and north-eastern Brazilian coasts. ZooKeys 688: 111-134. https://doi.org/10.3897/zookeys.688.12636

\begin{abstract}
Marine mammal stranding events are used as an important tool for understanding cetacean biology worldwide. Nonetheless, there are vast gaps of knowledge to be filled in for a wide range of species. Reputable information is required regarding species from large baleen whales to sperm and beaked whales, as well as pelagic dolphins. This paper describes new cetacean records from north and north-eastern Brazil, which are both the least surveyed areas regarding aquatic mammals. Regular beach surveys were conducted to recover cetacean carcasses along the coast of Pará beginning November 2005. At the coasts of the Maranhão and Piauí states, the surveys were conducted between 2003 and 2013. From 2003 to 2014, 34 strandings of cetaceans were registered. The study provides four additional species records' in the area based on
\end{abstract}

Copyright Alexandra Fernandes Costa et al. This is an open access article distributed under the terms of the Creative Commons Attribution License (CC BY 4.0), which permits unrestricted use, distribution, and reproduction in any medium, provided the original author and source are credited. 
strandings (Balaenoptera borealis, Balaenoptera physalus, Peponocephala electra, and Pseudorca crassidens). A mass stranding of Guiana dolphins (Sotalia guianensis, $\mathrm{N}=12$ ), the most common species for the region, was reported for the first time. The records presented herein are of special concern, since they expand the knowledge on cetaceans from the Brazilian coast. In addition, this study conducted an analysis to verify the similarity between cetacean compositions described for north and north-eastern Brazil and the southern Caribbean region. The results showed a high similarity between these regions, proving the connection with the Caribbean cetacean fauna.

\section{Keywords}

Amazon, Balaenopteridae, beach survey, cluster analysis, Delphinidae, marine mammals distribution, Physeteridae, South America

\section{Introduction}

The Amazon Coastal Zone (ACZ), between $4^{\circ} \mathrm{N}$ and $4^{\circ} \mathrm{S}$, presents a singular environment, characterized by the immense discharge of the Amazon River. ACZ is an unique aquatic ecosystem where the largest continuum of mangrove belt of the world is found (Souza-Filho et al. 2005). These characteristics combined with the recent coral reef ecosystem discovered in the mouth of the Amazon (Moura et al. 2016) make this region a top priority for conservation among Brazilian coastal environments. In this vast coastal area cetacean records have been documented only in the last decade. The north and north-eastern Brazil have been one of the least surveyed areas regarding aquatic mammals. Only one report made a compilation of cetacean records from this area (Siciliano et al. 2008) bringing the number of recorded species to 22, including large whales and dolphins. This study is an effort to increase this information after abovementioned study. Stranding events is one of the best ways to access data on biology and ecology of marine mammals (Norman et al. 2004, Evans et al. 2005, Pyenson 2010, Santos et al. 2010, Peltier et al. 2012, Covelo et al. 2015).

The cetacean fauna of Brazil has been subject to an extensive number of groups dedicated to conservation and research issues since the 1980's. Because of this, a considerable amount of new information on cetacean distribution, biology and ecology has arisen (e.g. Pinedo et al. 2001; Zerbini et al. 2004). In 2005, with the establishment of the 'Grupo de Estudos de Mamíferos Aquáticos da Amazônia (GEMAM)' at the Museu Paraense Emílio Goeldi, the first systematic studies on aquatic mammals were initiated in the region.

Nevertheless, there are vast gaps of knowledge to be filled in for a wide range of species. From large baleen whales to sperm and beaked whales, as well as pelagic dolphins, reputable information is required. This is due, in part, to the lack of inventories over large areas of the Brazilian coast.

Studies on the occurrence of cetaceans around the world are made using different methodologies such as: strandings, historical records, opportunistic sightings, and dedicated surveys (Maldini et al. 2005, Lucena 2006, Toledo and Langguth 2009, Ramos et al. 2010, Authier et al. 2014, Prado et al. 2016). In other words, cetacean com- 
position in a specific area could be assessed through strandings when other sources of information are not available (Maldini et al. 2005, Byrd et al. 2014, Jung et al. 2015). In this sense, Pyenson (2010) validated that cetacean death assemblages is a faithful method to document taxonomic richness and relative abundance of living cetaceans.

The main goals of this report are to: (1) present a variety of new cetacean records along the northern Brazilian coast, (2) increase baseline information on cetacean occurrence over 11 years (2003-2014); and (3) compare the cetacean composition in distinct areas along the north and north-eastern Brazilian coasts with southern Caribbean region, investigating the similarity between these sectors. The results of this study could open a promising new window for understanding the cetacean community structure in this vast stretch of coast.

\section{Materials and methods}

\section{Study sites}

The northern Brazilian coast has Cabo Orange as its limits to the north $\left(05^{\circ} \mathrm{N}, 51^{\circ} \mathrm{W}\right)$, and São José Bay to the south $\left(02^{\circ} \mathrm{S}, 44^{\circ} 15^{\prime} \mathrm{W}\right)$ and represent the Atlantic coastal sector. This vast coastal area extends for approximately $2250 \mathrm{~km}$ composed of different systems: mangrove forests, salt marshes, tidal sand flats, chenier sand ridges, coastal dunes, beach ridge barriers, and ebb tidal delta (Souza-Filho et al. 2008). The semi-diurnal macro-tidal regime with variations of approximately $4 \mathrm{~m}$ in Marajó Bay and 7.5 $\mathrm{m}$ in São José Bay (DHN 2010) is another characteristic. Also, the ecosystem in this region is strongly influenced by rain season (high precipitation, low salinity, and high turbidity) and dry season (low precipitation, high salinity, and low turbidity) (Moraes et al. 2005). The freshwater input along this coastline is different. In the northern the influence of the enormous discharge of the Amazon River dominates, while in the eastern coast of Maranhão and in the coastline of Piauí, the principal effect comes from the discharge of Parnaíba River (Szczygielski et al. 2014).

The study site of this report is divided into three sampling sectors: (1) Marajó Bay (MB), (2) Eastern Pará state (EP) and (3) Maranhão/Piauí coastline (MA/PI), encompassing part of Parnaíba Delta (Fig. 1).

Marajó Bay is located on the eastern coast of Marajó Island (Fig. 1, frame 1). This bay is formed mainly by the discharges of Pará and Tocantins rivers and Guajará Bay and is influenced by oceanographic processes such as superficial saline intrusion during dry season under low river discharges.

In the eastern coast of Pará (Fig. 1, frame 2) and north-west coast of Maranhão the coastline is designated as Amazon macrotidal coastal zone. This region encompass almost $70 \%$ of Brazilian mangrove forests, possess low relief ( 0 to $80 \mathrm{~m}$ ), broad coastal plain (with up to $70 \mathrm{~km}$ wide) and large continental shelf (200 km approximately). This coastline is extremely irregular and forms numerous bays and small estuaries, the area is influenced for a macrotidal regime (Souza-Filho 2005). 


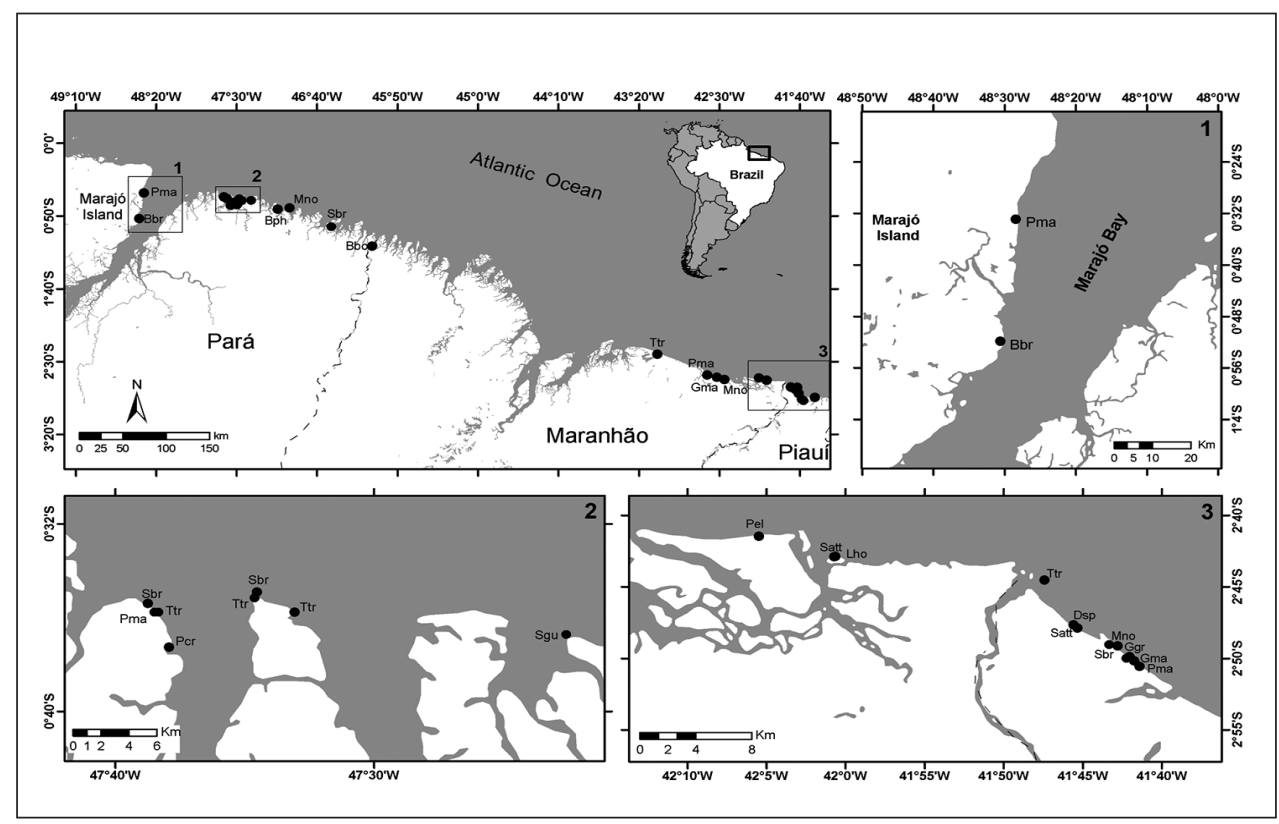

Figure I. Study sites. Surveyed sectors on north and north-eastern Brazilian coast: I Marajó Bay 2 Eastern Pará state and $\mathbf{3}$ Maranhão and Piauí coastlines encompass part of Parnaíba Delta. Black dots representing stranding locations. Physeter macrocephalus (Pma), Balaenoptera brydei (Bbr), Balaenoptera physalus (Bph), Megaptera novaeangliae (Mno), Steno bredanensis (Sbr), Balaenoptera borealis (Bbo), Tursiops truncatus (Ttr), Globicephala macrorhynchus (Gma), Pseudorca crassidens (Pcr), Sotalia guianensis (Sgu), Peponocephala electra (Pel), Stenella attenuata (Sat), Lagenodelphis hosei (Lho), Delphinus sp. (Dsp) and Grampus griseus (Ggr).

Maranhão and Piauí coastlines, encompassing the Parnaíba Delta (Fig. 1, frame 3), are considered a semiarid region. Parnaíba River discharge into the Atlantic Ocean forming a delta with five bays: Tutóia, Caju, Melancieiras, Canárias and Igaraçu (Moreira and Mavigner 2007). Parnaíba Delta comprises a mesotidal coast with beaches with up to $200 \mathrm{~m}$ wide and large areas of mangrove forests (Szczygielski et al. 2014).

Stranding events in these areas were regularly monitored between 2005 and 2014 in MB and EP sampling sectors, and from 2003 to 2013 in MA/PI sector (Fig. 1, see frame 1 and 2). Every two-week period, the vast stretch of coastline is reached by boat and four-wheel vehicle or, alternatively, monitored by foot. At least three field monitors take part in the field and on dedicated surveys the same routes were covered.

On occasion, the team was called to respond to live strandings or carcasses washed ashore. These events, as they are exclusive in their nature and circumstances, are validated with voucher samples, photographs, and other sources of original information.

The carcasses were identified in the field following specific features (e.g. colouration, shape of the head and fins/flippers, number of teeth). In such specific cases as Delphinus sp. and Megaptera novaeangliae, the identification was made posteriorly through cranial measures and scapular features, respectively. 
Complete and incomplete carcasses were recovered and their skeletons and soft tissues, after preparation, are deposited at the Mammal Collection from Museu Paraense Emílio Goeldi (MPEG), located in Belém, Pará, Brazil. Table 1 lists the records of cetaceans stranded from 2003 to 2014 on the northern and north-eastern Brazilian coast according to the three sampling sectors, including voucher numbers from the abovementioned collection.

\section{Data source and analysis}

The similarity between the cetacean composition described in this study and the most representative surveys conducted in the north (Siciliano et al. 2008) and part of the north-eastern Brazilian coasts (Alves-Júnior et al. 1996, Motta et al. 2008, Meirelles et al. 2009), in addition to the Caribbean region (Romero and Creswell 2005, Luksenburg 2014a, 2014b), was analyzed.

Similarities between the stranding and sighting records of cetaceans reported in seven articles and the present study was accomplished through an analysis of similarity by the Jaccard index based on the presence or absence of species. A similarity profile (SIMPROF) test was performed to detect the significantly different groups using the default of 1.000 permutations for the mean similarity profile and 999 permutations for the simulated profile, with a significance level of 0.05 . Multivariate analyses were performed using PRIMER 6.0 (PRIMER-E Ltd., Plymouth, U.K) (Clarke and Gorley 2006).

\section{Results}

\section{Species richness and diversity}

The present study recorded rare strandings of some cetacean species (e.g. mass stranding of Sotalia guianensis), and the first occurrence of these cetaceans in northern coast: 1. Sei whale, Balaenoptera borealis Lesson, 1828, 2. Fin whale, Balaenoptera physalus (Linnaeus, 1958), 3. Melon-headed whale, Peponocephala electra (Gray, 1846) and 4. False killer whale, Pseudorca crassidens (Owen, 1846).

Species richness was represented for 15 taxa, within three distinct families: Balaenopteridae (B. borealis, B. physalus, B. brydei, M. novaeangliae), Physeteridae (P. macrocephalus) and Delphinidae (Delphinus sp., G. macrorhynchus, G. griseus, Lagenodelphis hosei, P. electra, P. crassidens, S. guianensis, S. attenuata, S. bredanensis, T. truncatus) (Table 1).

\section{Spatial distribution}

In these sampling sectors $(\mathrm{MB}=$ Marajó bay; $\mathrm{EP}=$ Eastern Pará; $\mathrm{MA} / \mathrm{PI}=$ Maranhão/Piauí coastline) stranding events were distributed unequally. The spatial distribution among 
Table I. Cetacean records from 2003 to 2014 on the northern Brazilian coast.

\begin{tabular}{l|c|c|c|c|c|c|c}
\hline \multicolumn{1}{c|}{ Species by Family } & Category & TL $(\mathbf{m})$ & Sex & Sector & Date & Voucher specimens \\
\hline Balaenopteridae & LS & 10.32 & F & EP & $13 / 09 / 2008$ & MPEG 39691 \\
\hline Balaenoptera borealis & CA & 4.20 & NI & MB & $15 / 09 / 2012$ & MPEG 42154 \\
\hline Balaenoptera brydei & LS & 14.90 & M & EP & $21 / 01 / 2010$ & MPEG 39690 \\
\hline Balaenoptera physalus & CA & 16.70 & F & MA/PI & $15 / 01 / 2003$ & - \\
\hline \multirow{4}{*}{ Megaptera novaeangliae } & CA & - & NI & MA/PI & 2005 & - \\
\cline { 2 - 7 } & CA & $10.00^{*}$ & M & EP & $08 / 10 / 2008$ & MPEG 39692 \\
\cline { 2 - 7 } & CA & $13.00^{*}$ & NI & MA/PI & $22 / 05 / 2009$ & MPEG 42184 \\
\hline
\end{tabular}

\section{Physeteridae}

\begin{tabular}{|c|c|c|c|c|c|c|}
\hline \multirow{4}{*}{ Physeter macrocephalus } & CA & 11.80 & $\mathrm{~F}$ & $\mathrm{MA} / \mathrm{PI}$ & $02 / 02 / 2010$ & MPEG 42088 \\
\hline & $\mathrm{CA}$ & - & $\mathrm{F}$ & MA/PI & $14 / 05 / 2010$ & MPEG 42173 \\
\hline & LS & 10.50 & $\mathrm{~F}$ & EP & $07 / 04 / 2014$ & MPEG 42177 \\
\hline & $\mathrm{CA}$ & 4.22 & $\mathrm{NI}$ & $\mathrm{MB}$ & 08/08/2014 & MPEG 42178 \\
\hline \multicolumn{7}{|l|}{ Delphinidae } \\
\hline Delphinus sp. & CA & 2.06 & NI & MA/PI & $12 / 08 / 2011$ & MPEG 42095 \\
\hline \multirow{2}{*}{ Globicephala macrorhynchus } & $\mathrm{CA}$ & - & $\mathrm{NI}$ & $\mathrm{MA} / \mathrm{PI}$ & 2009 & - \\
\hline & $\mathrm{CA}$ & - & $\mathrm{NI}$ & $\mathrm{MA} / \mathrm{PI}$ & $15 / 01 / 2009$ & MPEG 42128 \\
\hline Grampus griseus & CA & - & NI & $\mathrm{MA} / \mathrm{PI}$ & $13 / 04 / 2011$ & MPEG 42130 \\
\hline Lagenodelphis hosei & LS & - & $\mathrm{M}$ & $\mathrm{MA} / \mathrm{PI}$ & 03/04/2009 & MPEG 42080 \\
\hline \multirow{2}{*}{ Peponocephala electra } & $\mathrm{CA}$ & - & $\mathrm{NI}$ & $\mathrm{MA} / \mathrm{PI}$ & 2007 & MPEG 42067 \\
\hline & $\mathrm{CA}$ & - & $\mathrm{NI}$ & MA/PI & $19 / 06 / 2008$ & MPEG 42069 \\
\hline Pseudorca crassidens & $\mathrm{CA}$ & 3.30 & $\mathrm{NI}$ & $\mathrm{EP}$ & $20 / 04 / 2012$ & MPEG 42132 \\
\hline Sotalia guianensis & LS & - & NI & EP & $31 / 01 / 2013$ & - \\
\hline \multirow{2}{*}{ Stenella attenuata } & $\mathrm{CA}$ & - & $\mathrm{NI}$ & $\mathrm{MA} / \mathrm{PI}$ & $14 / 03 / 2009$ & MPEG 42077 \\
\hline & CA & 1.59 & M & MA/PI & $10 / 12 / 2009$ & MPEG 42085 \\
\hline \multirow{6}{*}{ Steno bredanensis } & $\mathrm{CA}$ & - & NI & EP & $19 / 04 / 2009$ & MPEG 39635 \\
\hline & $\mathrm{CA}$ & - & $\mathrm{NI}$ & $\mathrm{MA} / \mathrm{PI}$ & $15 / 08 / 2011$ & MPEG 42096 \\
\hline & $\mathrm{CA}$ & - & $\mathrm{NI}$ & EP & $20 / 11 / 2011$ & MPEG 42066 \\
\hline & $\mathrm{CA}$ & - & $\mathrm{NI}$ & EP & $20 / 11 / 2011$ & MPEG 42102 \\
\hline & $\mathrm{CA}$ & 2.68 & M & EP & $04 / 04 / 2012$ & MPEG 42131 \\
\hline & $\mathrm{CA}$ & - & $\mathrm{NI}$ & MA/PI & $23 / 08 / 2013$ & MPEG 42176 \\
\hline \multirow{6}{*}{ Tursiops truncatus } & $\mathrm{CA}$ & - & $\mathrm{NI}$ & MA/PI & $24 / 04 / 2009$ & MPEG 42129 \\
\hline & CA & - & $\mathrm{NI}$ & MA/PI & $26 / 07 / 2009$ & MPEG 42081 \\
\hline & $\mathrm{CA}$ & - & $\mathrm{NI}$ & MA/PI & 05/03/2010 & - \\
\hline & CA & - & NI & $\mathrm{EP}$ & $12 / 03 / 2010$ & MPEG 39612 \\
\hline & $\mathrm{CA}$ & 3.17 & $\mathrm{M}$ & EP & $13 / 02 / 2013$ & MPEG 42174 \\
\hline & CA & 2.87 & $\mathrm{~F}$ & $\mathrm{EP}$ & $04 / 03 / 2013$ & MPEG 42175 \\
\hline
\end{tabular}

Species were divided by family, details of specimens and stranding. Abbreviations: TL= total length in meters; $\mathrm{Sex}=$ female, male and not identified (NI); Category of stranding - live (LS) and carcass (CA), Date, sector and location of events; $\mathrm{MB}=$ Marajó bay; EP= Eastern Pará state; MA/PI= Maranhão/Piauí coastline * represents the estimated TL (specimens missing the skull) 
sectors showed that the majority of strandings occurred at the Maranhão/Piauí coastline $54.5 \%(\mathrm{~N}=18)$, on the north-eastern coast of Brazil. The EP occupies the second place, with $39.4 \%(\mathrm{~N}=13)$ and $\mathrm{MB}$ with only $6.1 \%(\mathrm{~N}=2)$ of rare cetacean records.

Differences in strandings by family and sector were analyzed in order to evaluate patterns along the distinct sectors of this coastline. Members of the Delphinidae family were the most representative in the frequency of strandings, comprising $66.7 \%(\mathrm{~N}$ = 22), followed by Balaenopteridae 21.2\% ( $\mathrm{N}=7)$ and Physeteridae $12.1 \%(\mathrm{~N}=4)$.

\section{Cetacean Composition}

\section{Balaenopteridae}

\section{Balaenoptera borealis Lesson, 1828}

\section{Sei whale}

On 13 September 2008 a large whale stranded alive on the eastern Pará state (EP). The specimen (MPEG 39691) had features characteristically attributed to Sei whales: a dark body with patches of lighter gray, both sides of head evenly dark, head slightly arched, throat grooves ending just behind the flippers, grey-black baleen plates with a metallic sheen, lighter plates near the front of the mouth and a sickle-shaped dorsal fin. After unsuccessful trials of pushing the whale back to the sea, it died (Fig. 2d). The necropsy revealed a large amount of mud in the stomach, probably originated from the mangrove sediments nearby the stranding site.

\section{Balaenoptera brydei Olsen, 1913}

\section{Bryde's whale}

On 15 September 2012 a decomposed carcass of a newborn B. brydei washed ashore on the rocky shore of Praia de Água Boa, Salvaterra, Marajó bay (MB), Pará (Fig. 2b). Partial skeleton and tissue samples were collected (MPEG 42154).

\section{Balaenoptera physalus (Linnaeus, 1958)}

\section{Fin whale}

On January 2010, a male Fin whale $B$. physalus was reported stranded on the eastern Pará state (EP) in Baía do Japerica, São João de Pirabas municipality. Fishermen and residents sighted the live specimen entering the estuary but a few days later the carcass was found stranded in a different location. The fresh specimen had a large callosity on the top of the head (Fig. 2a). The nearly complete skeleton, including skull and mandibles, is deposited in the mammal collection (MPEG 39690). 

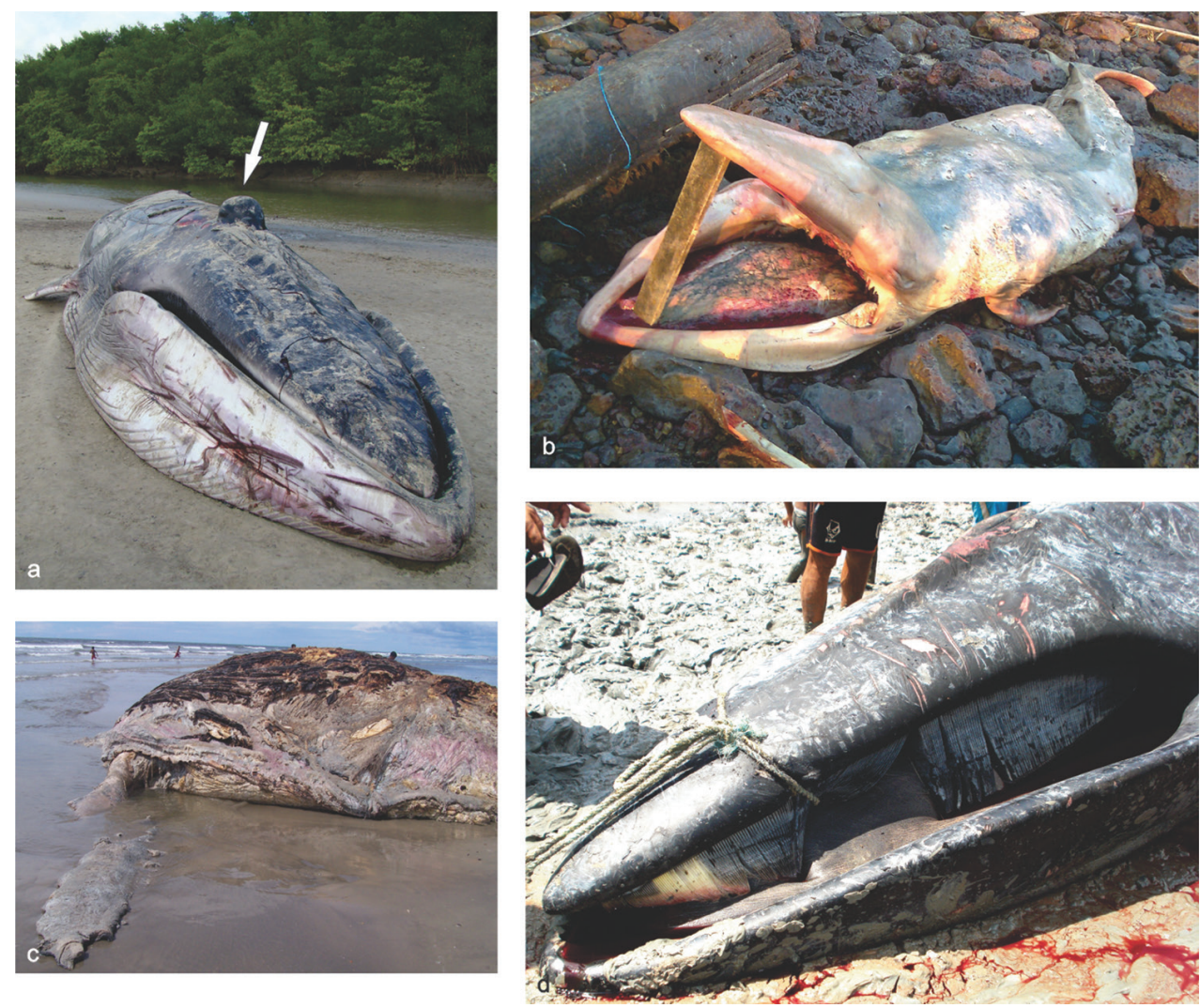

Figure 2. Stranding events: large baleen whales. a Fin whale Balaenoptera physalus stranded at Baía do Japerica, São João de Pirabas municipality $\left(0^{\circ} 45^{\prime} \mathrm{S}, 47^{\circ} 4.2^{\prime} \mathrm{W}\right)$, eastern coast of the Pará state. Note the good condition of the carcass and the strange swelling on the top of the head (see white arrow) (photo by GEMAM/MPEG) b A newborn Bryde's whale Balaenoptera brydei stranded on the east coast of Marajó island $\left(0^{\circ} 51.6^{\prime} \mathrm{S}, 48^{\circ} 30^{\prime} \mathrm{W}\right.$ ), Pará on 15 September 2012 (photo by GEMAM/MPEG) c Humpback whale Megaptera novaeangliae stranded at Praia do Rio Novo, Tutóia municipality, Maranhão state $\left(2^{\circ} 42.6^{\prime} \mathrm{S}\right.$, $42^{\circ} 26.4^{\prime} \mathrm{W}$ ), note the absence of skull on the carcass (photo by A.F. Costa) d Sei whale Balaenoptera borealis stranded at Fernandes Belo, Viseu municipality $\left(1^{\circ} 10.8^{\prime} \mathrm{S}, 46^{\circ} 5.4^{\prime} \mathrm{W}\right)$, the particular coloration of the baleen plates and slightly arched head are diagnostic characters to identify the species (photo by DEMA/PA).

\section{Megaptera novaeangliae (Borowski, 1781)}

\section{Humpback whale}

The first evidence of a Humpback whale $M$. novaeangliae in Piauí is represented by a female stranded at Praia da Pedra do Sal, Parnaíba on 15 January 2003. Subsequently, in 2005, locals collected a scapula at Praia da Carnaubinha, Luís Correia municipality. On May 2009, a decomposed carcass missing the skull was found stranded in the Praia do Rio Novo, Tutóia municipality, voucher No MPEG 42184 (Fig. 2c). 

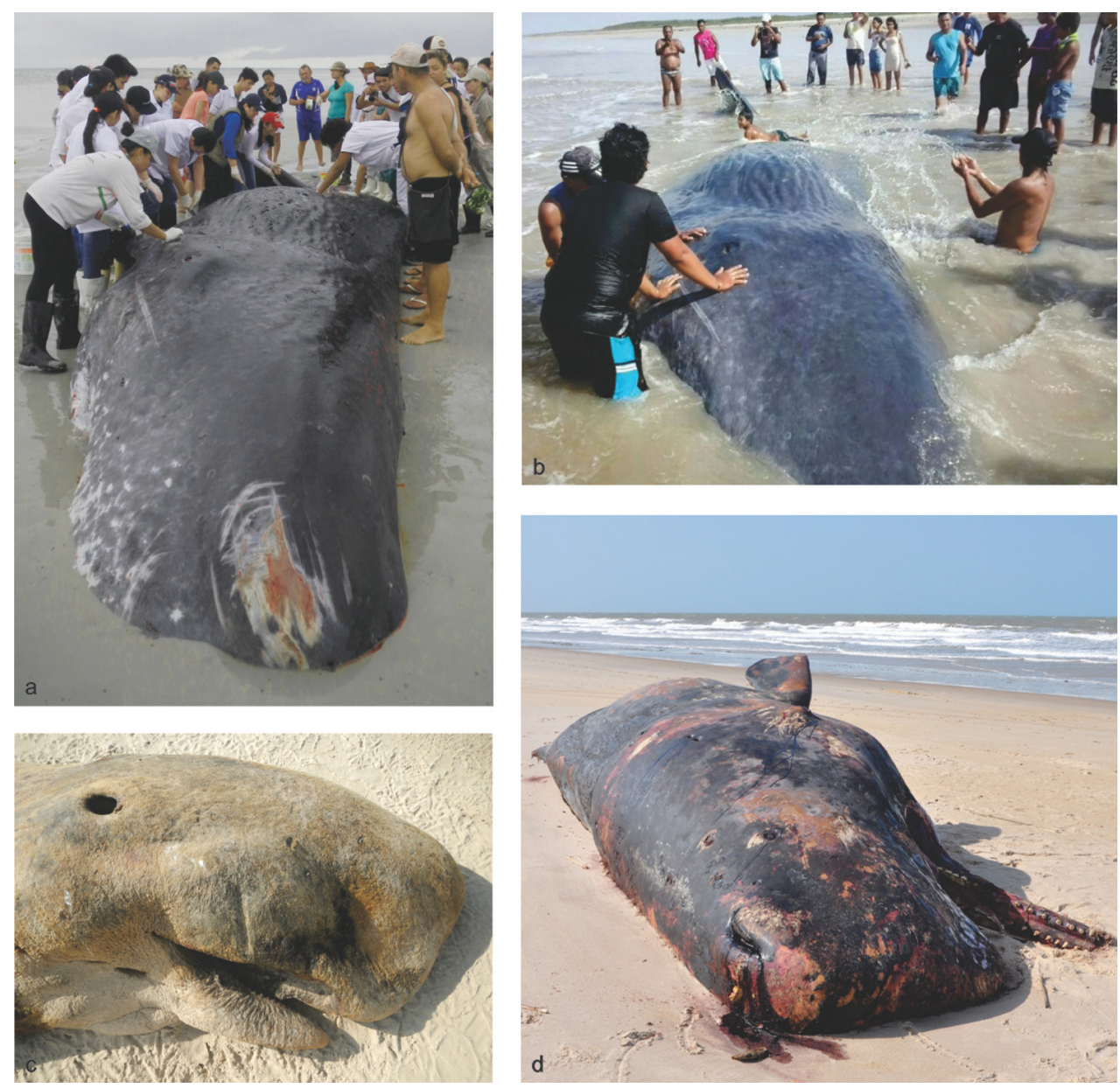

Figure 3. Stranding events: sperm whales. a Sperm whale Physeter macrocephalus (MPEG 42166) stranded at Praia do Crispim, Marapanim municipality $\left(0^{\circ} 34.8^{\prime} \mathrm{S}, 47^{\circ} 38.4^{\prime} \mathrm{W}\right)$ eastern coast of Pará state few hours after death (photo by A.F. Costa) b The same specimen (MPEG 42166) still alive with local people trying to help (internet file) c A newborn Sperm whale (MPEG 42178) stranded at the east coast of Marajó island, Praia do Camburupy $\left(0^{\circ} 32.4^{\prime} \mathrm{S}, 48^{\circ} 28.2^{\prime} \mathrm{W}\right)$ on 2014 , note the absence of teeth characteristic of a very young specimen (photo by A.F. Costa) d A female Sperm whale (MPEG 42088) stranded at Praia da Pedra

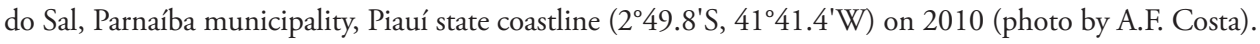

\section{Physeteridae}

\section{Physeter macrocephalus Linnaeus, 1758}

\section{Sperm whale}

On 02 February 2010 a female with TL $=11.80 \mathrm{~m}$ (MPEG 42088) stranded at Praia da Pedra do Sal, Parnaíba municipality, Piauí state (Fig. 3d). The carcass was moderately fresh, had numerous bites of cookie-cutter shark (Isistius sp.) over the body and evidence of endoparasites in the blubber. The remains of a second specimen, also a 
female, stranded at Praia do Baixo da Boia, Paulino Neves municipality, Maranhão state on 14 May 2010. Some vertebrae and chevrons with deformations were recovered (MPEG 42173). On 07 April 2014, a live-stranded Sperm whale was recorded for the first time along the Pará coastline. The specimen was a female with $\mathrm{TL}=10.50 \mathrm{~m}$ (MPEG 42166) that came ashore at Praia do Crispim (Fig. 3a, b), had a large amount of squid beaks in its stomach and intestines. On 08 August 2014, a very young specimen $(\mathrm{TL}=4.22 \mathrm{~m})$ stranded at east coast of the Marajó Island in Praia do Camburupy, Soure municipality. Sex was not determined due to the advanced decomposition of the carcass (Fig. 3c).

\section{Delphinidae}

\section{Oceanic species}

Delphinus sp. Gray, 1828

\section{Common dolphin}

On 12 August 2011 a decomposed delphinid carcass was found at Praia da Pedra do Sal, Parnaíba municipality, Piauí (MA/PI coastline) (MPEG 42095). This is the very first record of a Common dolphin for this portion of the Brazilian coast.

\section{Lagenodelphis hosei Fraser, 1956}

\section{Fraser's dolphin}

On the coast of the Maranhão state, at Praia da Barrinha, Canárias Island, the carcass of a Fraser's dolphin Lagenodelphis hosei was found fresh by fishermen on 03 April 2009, after it presumably live-stranded on the beach. The carcass was divided up at the village of Carnaubeira, Araioses municipality (Fig. 4a) and consumed locally (meat slices were found drying on clothes-line in villagers' houses).

\section{Stenella attenuata (Gray, 1846)}

\section{Pantropical spotted dolphin}

The Pantropical spotted dolphin S. attenuata is represented by two records from the MA/PI sector, both from 2009. Bone remains were found at the Canárias Island, Praia da Barrinha, Maranhão (MPEG 42077) and a decomposed carcass of a male was found at Praia da Pedra do Sal, Parnaíba municipality, Piauí (MPEG 42085), with marks of human interaction. 

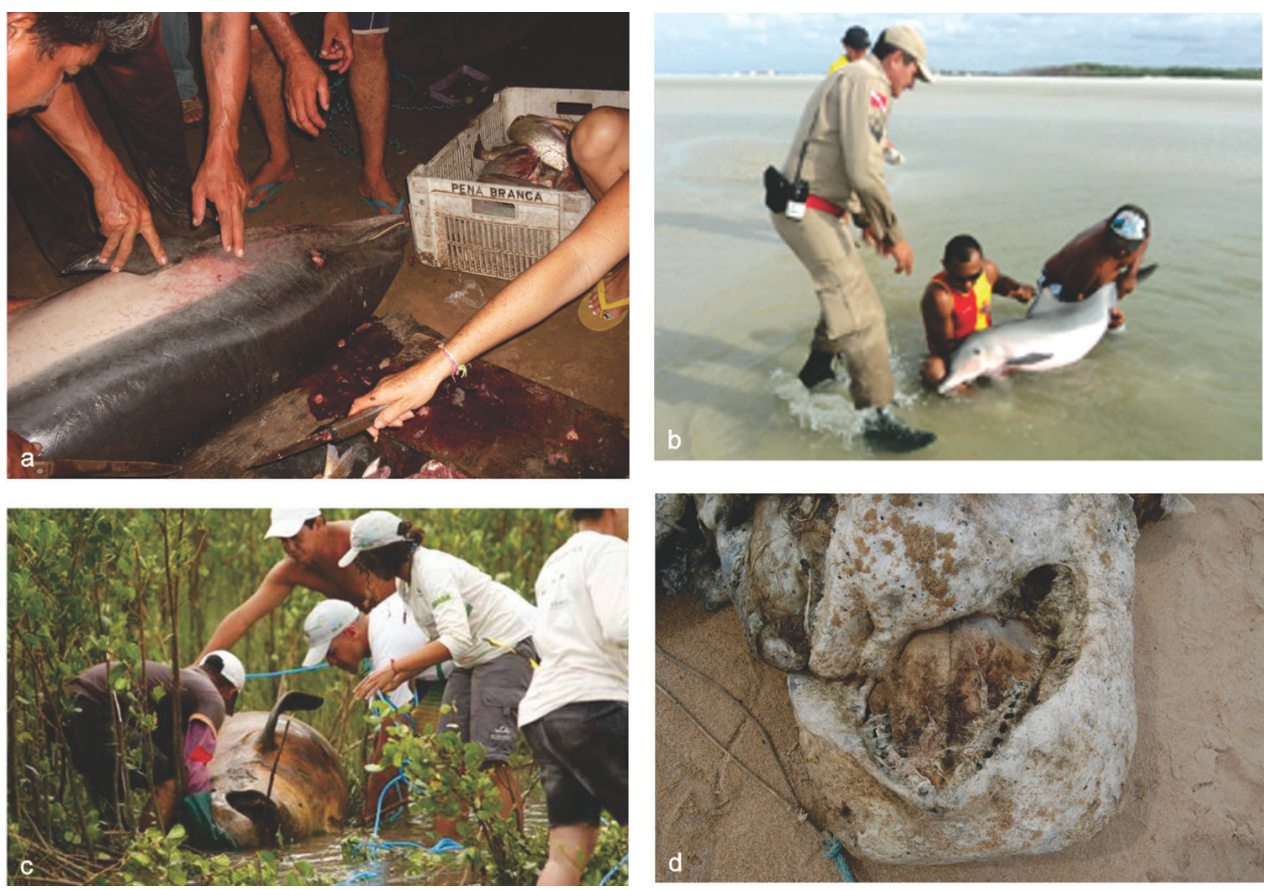

Figure 4. Stranding events: small and medium-sized cetaceans. a The carcass of a Fraser's dolphin, Lagenodelphis hosei was cut down on the village of Carnaubeira, Araioses municipality $\left(2^{\circ} 42.6^{\prime} \mathrm{S}\right.$, $42^{\circ} 0.6^{\prime} \mathrm{W}$ ) and consumed locally (photo PROCEMA files) b A group of 12 live Guiana dolphins Sotalia guianensis were found trapped (photo showed just one specimen) in a tidal channel alongside Corvina beach, Salinópolis municipality, eastern Pará $\left(0^{\circ} 36^{\prime} \mathrm{S}, 47^{\circ} 22.2^{\prime} \mathrm{W}\right)$ c A False killer whale Pseudorca crassidens stranded on the north-eastern coast of Pará, Praia de Marudá, Marapanim municipality (photo GEMAM files) d A Short-finned pilot whale Globicephala macrorhynchus stranded in advanced stage of decomposition at Praia da Pedra do Sal, Parnaíba municipality $\left(2^{\circ} 40.8^{\prime} \mathrm{S}, 42^{\circ} 31.2^{\prime} \mathrm{W}\right)$, the shape of the head and number of teeth were diagnostic to identify the species (photo PROCEMA files).

\section{Blackfish}

A Short-finned pilot whale Globicephala macrorhynchus Gray, 1846 was found stranded in an advanced state of decomposition in the Parnaíba municipality, Piauí (MA/PI), on 15 January 2009 (MPEG 42128). Identification was made possible through a combination of head features and tooth counts (Fig. 4d). In August 2009, during beach surveys at the Maranhão coast, the photographic record of a mounted skeleton on display in a beach tent was confirmed as $G$. macrorhynchus at the locality of Paulino Neves (MA/PI).

An incomplete Risso's dolphin skull Grampus griseus (G. Cuvier, 1812) (MPEG 42130) found buried was recovered at Praia da Pedra do Sal, Parnaíba municipality, Piauí, MA/PI sector, on 13 April 2011. 
Two stranding records of Melon-headed whale Peponocephala electra (Gray, 1846) were reported for the Ilha do Caju and Delta do Parnaíba (MA/PI). Only bone remains were recovered (MPEG 42067, MPEG 42069).

The first record of a False killer whale Pseudorca crassidens (Owen, 1846) on the Pará coastline occurred on 20 April 2012. The carcass was found in the mudflats at Praia de Marudá (Fig. 4c), Marapanim municipality, eastern Pará (EP). The specimen (MPEG 42132) had marks of human interaction; the peduncle was cut-off and most of the teeth were removed.

\section{Coastal species}

\section{Sotalia guianensis (Van Bénedén, 1864)}

\section{Guiana dolphin}

On 31 January 2013, 12 Guiana dolphins S. guianensis were reported as trapped in a tidal channel alongside Praia da Corvina, Salinópolis municipality, eastern Pará state (Fig. 4b, see Suppl. materials 1 and 2). They were all rescued by life savers and locals, who carried the dolphins along $700 \mathrm{~m}$ to the receding waters during the low tide. This event could be considered a mass stranding of Guiana dolphins, so far the first reported for the northern coast of Brazil, and presumably in the country.

\section{Steno bredanensis (G. Cuvier in Lesson, 1828)}

\section{Rough-toothed dolphin}

On 04 April 2012, the carcass of a mature male (MPEG 42131) Rough-toothed dolphin $S$. bredanensis stranded in a moderate state of decomposition showed bites and a huge scar on the caudal peduncle, which could indicate interaction with long line fisheries. New records of rough-toothed dolphins were confirmed from EP, MPEG 39635 (Praia da Princesa, Algodoal Island, Maracanã municipality), MPEG 42066/ MPEG 42102 (Praia do Crispim, Marapanim municipality) and from MA/PI coastline, MPEG 42096/MPEG 42176 (Praia da Pedra do Sal, Parnaíba municipality).

\section{Tursiops truncatus (Montagu, 1821)}

\section{Bottlenose dolphin}

Five new records of Bottlenose dolphin T. truncatus were reported after the previous review by Siciliano et al. (2008) (see Table 1 for complete information). On 5 March 2010, in Praia da Travosa, Santo Amaro municipality, Maranhão (MA/PI) (See Suppl. material 3), a young Bottlenose dolphin T. truncatus was found live-stranded on a beach and was rescued by bathers, locals and fishermen. 


\section{Cluster analysis}

The cluster analysis indicated that the cetacean composition from the Caribbean and north Brazilian coast form a single group (Group 1) that differs significantly from the group formed at north-eastern Brazil (Group 2) (Fig. 5).

The richness of species varied from 13 to 24, with 29 species in totality. Group 2 was defined by adding stranding information from north-eastern Brazil (Alves-Júnior et al. 1996, Motta et al. 2008, Meirelles et al. 2009). Species richness ranged from 5 to 10 , with 15 species in total.

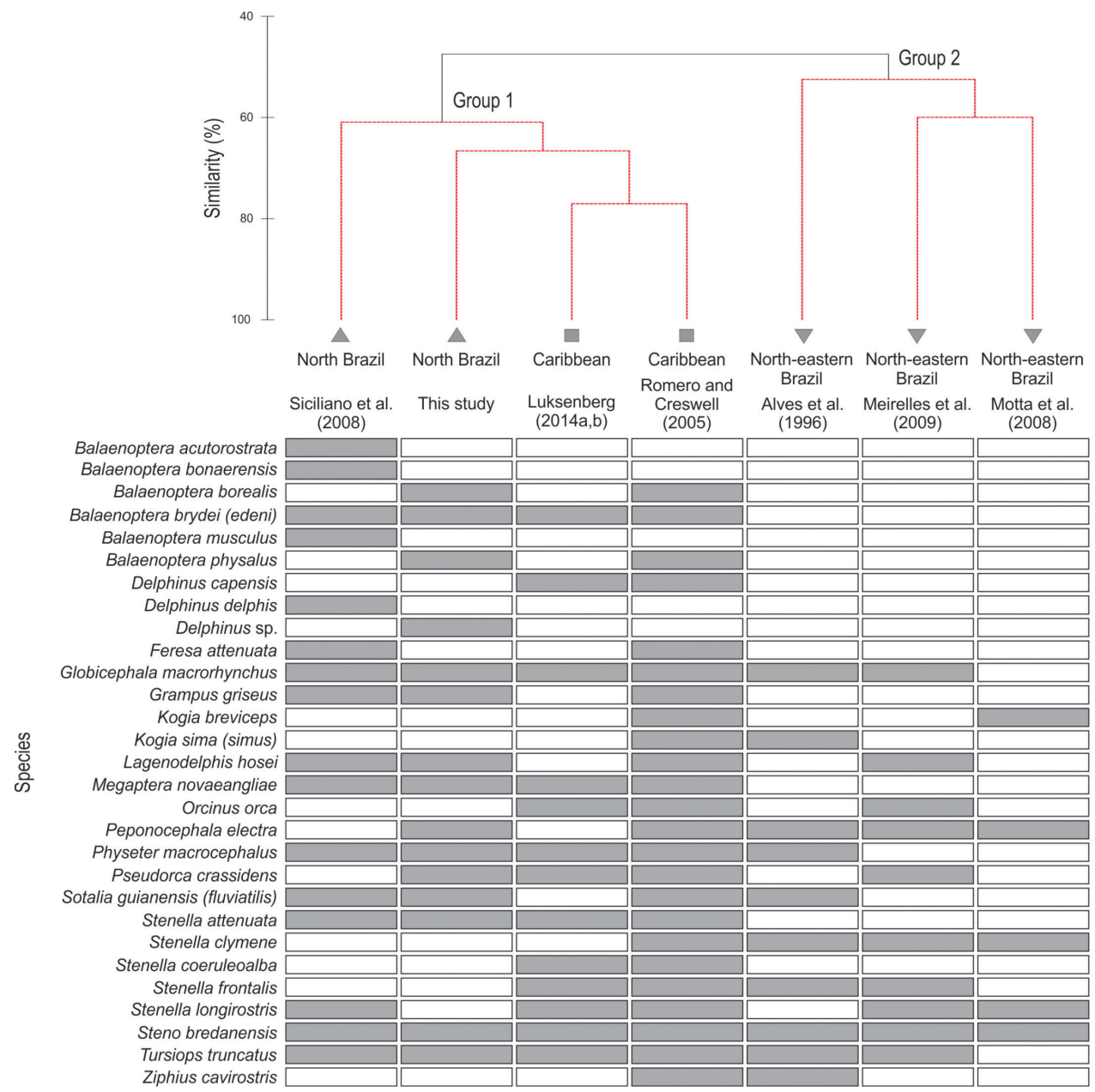

Figure 5. Cluster analysis of cetacean stranding and sighting records. Diagram of cetaceans reported from the north-eastern (inverted triangle) and north coast of Brazil (triangle) and southern Caribbean (square), reported in seven articles and the present study. The two distinct groups formed (Group 1 and 2) are indicated. A similarity profile (SIMPROF) permutation test highlights dashed clusters that show significant internal structure. Shaded cells indicate occurrence of species. 


\section{Discussion}

Stranding data are an important source to understanding the biology and ecology of marine mammals (Geraci and Lounsbury 1993, Moura and Siciliano 2012, Covelo et al. 2015). Indeed, the records presented herein are of particular importance, as they clarify the composition and richness of the cetacean community in a vast stretch of the Brazilian coast. Current data, with the addition of four species to the previous list (Siciliano et al. 2008), expanded this number to 26 aquatic mammal species. This study is in accordance to (Pyenson 2010) which suggests that stranding records at extensive latitude gradients $(>1000 \mathrm{~km})$ and for long time periods, provide an useful and faithfully method to understand richness and cetacean community in a particular area than the sighting surveys (e.g. line-transect method). Maldini et al. (2005) analyzing the composition of cetaceans of the Hawaiian Islands suggested that the stranding data reflects the species composition found in living animals surveys and defends the usefulness use of stranding data as an important source of information in the absence of other data. Marine mammalogists assumed that stranding events could be affected by oceanographic features such as bottom topography, tides, currents, winds and seasonal patterns (Norman et al. 2004). Carcasses can be moved by currents and winds along the coast and the oceanographic differences observed in this vast area of the north and north-eastern Brazilian coast should be considered important factors on stranding distributions. This coastline is singular and considered a continuous belt of mangroves with approximately $7591 \mathrm{~km}^{2}$ (Souza-Filho 2005) which complicates access and, consequently the rescue and reports of stranded marine mammals. The macrotidal characteristic observed in the Marajó Bay and Eastern Pará sectors is another factor that should explain the low frequency of strandings especially of small and medium-sized cetaceans. The dynamic of macrotidal regime may in a few hours carry the carcass of a small cetacean without it could be seen in these vast uninhabited areas.

The spatial distribution of species in the three sectors (MB, EP and MA/PI coastline) provides relevant information on their occurrence through stranding notifications. Small pelagic and neritic-pelagic cetaceans have been recorded in higher numbers along the EP and MA/PI sectors. In contrast, the MB area and adjacent coastline are influenced by the Amazon and Pará/Tocantins Rivers discharges, thus presumably limiting the occurrence and subsequent stranding of pelagic species. It should be considered that areas of difficult access and sparsely populated in the Amazon coastal zone, as the eastern Pará and the western Maranhão states, could represent potential circumstances for the low stranding notifications in these sectors. Although the systematic monitoring effort was lower at Maranhão/Piauí coastline, this area resulted to be singular due to the exclusive cetacean records of pelagic and neritic-pelagic species (e.g. Lagenodelphis hosei, Peponocephala electra). Despite the surveys were more dedicated in the MB sector, the frequency of uncommon strandings (e.g. oceanic species) were lower. However, single strandings of Sotalia guianensis, Inia geoffrensis and I. araguaiaensis in MB are not included in this report as they are commonplace and will be analyzed separately. 
Table 2. Localities of marine mammal strandings and other localities mentioned in this study.

\begin{tabular}{|c|c|c|c|c|}
\hline Locality & Municipality & Lat & Long & Description (species, others) \\
\hline Cabo Orange & Oiapoque & $5^{\circ} \mathrm{N}$ & $51^{\circ} \mathrm{W}$ & northern Brazilian coast to the west \\
\hline Ponta do Tubarão & Baía de São José & $4^{\circ} 00^{\prime} \mathrm{S}$ & $43^{\circ} 00^{\prime} \mathrm{W}$ & northern Brazilian coast to the east \\
\hline Fernandes Belo & Viseu & $1^{\circ} 10.8^{\prime} \mathrm{S}$ & $46^{\circ} 5.4^{\prime} \mathrm{W}$ & Balaenoptera borealis \\
\hline Praia de Água Boa & Salvaterra & $0^{\circ} 51.6 \mathrm{~S}$ & $48^{\circ} 30^{\prime} \mathrm{W}$ & Balaenoptera brydei \\
\hline Baía do Japerica & São João de Pirabas & $0^{\circ} 45^{\prime} \mathrm{S}$ & $47^{\circ} 4.2^{\prime} \mathrm{W}$ & Balaenoptera physalus \\
\hline Praia da Pedra do Sal & Parnaíba & $2 \% 49.15^{\prime} \mathrm{S}$ & $41^{\circ} 42.8^{\prime} \mathrm{W}$ & Megaptera novaeangliae \\
\hline Praia da Carnaubinha & Luís Correia & $2^{\circ} 54.77^{\prime} \mathrm{S}$ & $41^{\circ} 30.66^{\prime} \mathrm{W}$ & Megaptera novaeangliae \\
\hline Praia do Rio Novo & Tutóia & $2^{\circ} 42.6 ' \mathrm{~S}$ & $42^{\circ} 26.4^{\prime} \mathrm{W}$ & Megaptera novaeangliae \\
\hline Praia de Fora & Quatipurú & $0^{\circ} 44.4^{\prime} \mathrm{S}$ & $46^{\circ} 57^{\prime} \mathrm{W}$ & Megaptera novaeangliae \\
\hline Praia da Pedra do Sal & Parnaíba & $2^{\circ} 49.8^{\prime} \mathrm{S}$ & $41^{\circ} 41.4^{\prime} \mathrm{W}$ & Physeter macrocephalus \\
\hline Praia do Baixo da Boia & Paulino Neves & $2^{\circ} 37.2^{\prime} \mathrm{S}$ & $42^{\circ} 38.4^{\prime} \mathrm{W}$ & Physeter macrocephalus \\
\hline Praia do Crispim & Marapanim & $0^{\circ} 34.8^{\prime} \mathrm{S}$ & $47^{\circ} 38.4^{\prime} \mathrm{W}$ & Physeter macrocephalus \\
\hline Praia do Camburupy & Soure & $0^{\circ} 32.4^{\prime} \mathrm{S}$ & $48^{\circ} 28.2^{\prime} \mathrm{W}$ & Physeter macrocephalus \\
\hline Praia da Pedra do Sal & Parnaíba & $2^{\circ} 47.4^{\prime} \mathrm{S}$ & $41^{\circ} 45^{\prime} \mathrm{W}$ & Delphinus sp. \\
\hline Praia da Barrinha & Araioses & $2^{\circ} 42.6 ' \mathrm{~S}$ & $42^{\circ} 0.6^{\prime} \mathrm{W}$ & Lagenodelphis hosei \\
\hline Praia da Barrinha & Araioses & $2^{\circ} 42.6 ' \mathrm{~S}$ & $42^{\circ} 0.6^{\prime} \mathrm{W}$ & Stenella attenuata \\
\hline Praia da Pedra do Sal & Parnaíba & $2^{\circ} 47.4^{\prime} \mathrm{S}$ & $41^{\circ} 45^{\prime} \mathrm{W}$ & Stenella attenuata \\
\hline Praia da Pedra do Sal & Parnaíba & $2^{\circ} 49.8^{\prime} \mathrm{S}$ & $41^{\circ} 41.4^{\prime} \mathrm{W}$ & Globicephala macrorhynchus \\
\hline Paulino Neves & Paulino Neves & $2^{\circ} 40.8^{\prime} \mathrm{S}$ & $42^{\circ} 31.2^{\prime} \mathrm{W}$ & Globicephala macrorhynchus \\
\hline Praia da Pedra do Sal & Parnaíba & $2^{\circ} 49.8^{\prime} \mathrm{S}$ & $41^{\circ} 42^{\prime} \mathrm{W}$ & Grampus griseus \\
\hline Delta do Parnaíba & - & - & - & Peponocephala electra \\
\hline Ilha do Caju & Araioses & $2^{\circ} 41.4^{\prime} \mathrm{S}$ & $42^{\circ} 5.4^{\prime} \mathrm{W}$ & Peponocephala electra \\
\hline Praia de Marudá & Marapanim & $0^{\circ} 37.2^{\prime} \mathrm{S}$ & $47^{\circ} 37.8^{\prime} \mathrm{W}$ & Pseudorca crassidens \\
\hline Praia da Corvina & Salinopólis & $0^{\circ} 36^{\prime} \mathrm{S}$ & $47^{\circ} 22.2^{\prime} \mathrm{W}$ & Sotalia guianensis \\
\hline Praia de Ajuruteua & Bragança & $0^{\circ} 49.2^{\prime} \mathrm{S}$ & $46^{\circ} 36^{\prime} \mathrm{W}$ & Steno bredanensis \\
\hline Praia da Princesa & Maracanã & $0^{\circ} 34.2^{\prime} \mathrm{S}$ & $47^{\circ} 34.8^{\prime} \mathrm{W}$ & Steno bredanensis \\
\hline Praia do Crispim & Marapanim & $0^{\circ} 34.8^{\prime} \mathrm{S}$ & $47^{\circ} 38.4^{\prime} \mathrm{W}$ & Steno bredanensis \\
\hline Praia do Crispim & Marapanim & $0^{\circ} 34.8^{\prime} \mathrm{S}$ & $47^{\circ} 38.4^{\prime} \mathrm{W}$ & Steno bredanensis \\
\hline Praia da Pedra do Sal & Parnaíba & $2^{\circ} 49.2^{\prime} \mathrm{S}$ & $41^{\circ} 42.6^{\prime} \mathrm{W}$ & Steno bredanensis \\
\hline Praia da Pedra do Sal & Parnaíba & $2^{\circ} 48^{\prime} \mathrm{S}$ & $41^{\circ} 43.8^{\prime} \mathrm{W}$ & Steno bredanensis \\
\hline Praia da Princesa & Maracanã & $0^{\circ} 34.2^{\prime} \mathrm{S}$ & $47^{\circ} 34.8^{\prime} \mathrm{W}$ & Tursiops truncatus \\
\hline Praia da Moita Verde & Araioses & $2^{\circ} 43.8^{\prime} \mathrm{S}$ & $41^{\circ} 48^{\prime} \mathrm{W}$ & Tursiops truncatus \\
\hline Furo Velho & Maracanã & $0^{\circ} 35.4^{\prime} \mathrm{S}$ & $47^{\circ} 33^{\prime} \mathrm{W}$ & Tursiops truncatus \\
\hline Porto do Sossego & Marapanim & $0^{\circ} 36.6^{\prime} \mathrm{S}$ & $47^{\circ} 37.8^{\prime} \mathrm{W}$ & Tursiops truncatus \\
\hline Praia da Travosa & Santo Amaro & $2^{\circ} 21^{\prime} \mathrm{S}$ & $43^{\circ} 15^{\prime} \mathrm{W}$ & Tursiops truncatus \\
\hline Baía do Capim & - & $1^{\circ} 76^{\prime} \mathrm{S}$ & $44^{\circ} 83^{\prime} \mathrm{W}$ & $\begin{array}{c}\text { Sperm whale stranding at } \\
\text { Maranhão coast }\end{array}$ \\
\hline
\end{tabular}

Earlier records of balaenopterids on the Amazon coastal zone were performed by Siciliano et al. (2008) and Silva et al. (2013). Previous revised information on stranding and sighting records of baleen whales along the Brazilian coast post-1997 (Siciliano et al. 2011) emphasizes the relevance of the current records. They are the very first evidence of the Fin and Sei whales occurrence along the northern Brazilian coast. The stranding intervals in each case could be informative of their movements and migra- 
tion periods. The Sei whale was stranded in September 2008, during the peak migration period of southward migration (August-October) (sensu Best and Lockyer 2002). In accordance to these authors, the Viseu specimen (MPEG 39691), $\mathrm{TL}=10.32 \mathrm{~m}$ in length, is acceptable as the size of immature females caught off South Africa (range 10.7-13.7 m). The Fin whale stranding demands a more complex interpretation, since the specimen became stranded in January, by the time most large whales have already reached Antarctic and sub-Antarctic waters. Siciliano et al. (2011) reported on a Fin whale sighted in January 2004 off the Santos Basin. Our present record poses an intriguing question, whether this whale was of a southern hemisphere origin or truly representative of a northern hemisphere stock.

The newborn Bryde's whale recorded in Praia da Água Boa (MB) on 15 September 2012 is a remarkable record, since very limited information exists on the pregnancy and time of birth of this tropical balaenopterid and, in Brazil, information on the calving season is almost non-existent (Santos et al. 2010). Moura and Siciliano (2012) report on two newborns stranded only a few months apart in south-eastern Brazil (August and September). Our record was in September, agreeing with these authors previous observations and, thus, suggesting the same period of the year as a calving season for Bryde's whales off the northern Brazilian coast. Records of Humpback whales herein expands significantly the presence of the species westwards the north-eastern Brazilian coast. Pretto et al. (2009) reported the first occurrence of M. novaeangliae for eastern coast of Pará at Praia de Fora, Quatipuru municipality.

In relation to odontocetes, four additional Sperm whales records are included from the Pará state and Maranhão/Piauí coastlines. One of them is of a very young specimen $(\mathrm{TL}=4.22 \mathrm{~m})$ stranded at east coast of the Marajó Island. This record strongly suggests the existence of calving off in the northern Brazilian coast. Sperm whales are a regular component of cetaceans found stranded on the north-eastern coast of Brazil. For example, Meirelles et al. (2009) provided 26 records for the Ceará state alone over the period from 1993 to 2005. The sample includes specimens of all sizes, from a $3.53 \mathrm{~m}$ newborn to a $18.10 \mathrm{~m}$ bull male. It was assumed that the strandings took part mostly in spring, summer, and winter months, influenced by strong north-western winds, when carcasses have more chance of coming ashore. Magalhães et al. (2008) have contributed with two records of Sperm whales for the Maranhão coastline, during their short-term surveys from 2004 to 2006. Other records for the north-eastern coast include a newborn stranded near of Baía do Capim ( $\left.1^{\circ} 76^{\prime} \mathrm{S}, 44^{\circ} 83^{\prime} \mathrm{W}\right)$, Maranhão coast (S3 File), and four other specimens reported by Tosi et al. (2006). In a broader perspective, it is highly recommended to conduct future surveys in order to estimate Sperm whale density and abundance off the north and north-eastern Brazilian coasts. The structure of this Sperm whale population in relation to more southerly aggregations in Brazil deserves further studies and agreed with literature which report that females and immature males inhabit lower latitudes in subtropical and tropical oceans (Whitehead 2009).

Blackfish records were represented by the False killer whale, Melon-headed whale, Short-finned pilot whale, and Risso's dolphin recovered in distinct areas. These speci- 
mens improve the knowledge on blackfish occurrence off the northern Brazilian coast. The False killer listed in this study is noteworthy; this is the first record of this species in the region. The specimen (MPEG 42132) had marks of human interaction; the peduncle was cut-off and most of the teeth were removed. This strongly suggests interactions with the pelagic fishery activity. Such marks were also observed in a rough-toothed dolphin stranded in eastern Pará (MPEG 42131) and on a pantropical spotted dolphin found on Piauí (MPEG 42085), suggesting that this kind of negative interaction may be more common than previously thought. Luksenburg (2014a) has informed on injuries found in live small cetaceans off Aruba, in the southern Caribbean. The author reported that of the 18 False killer whales individuals presenting injuries, six (33.3\%) showed wounds that were probably caused by human activities. Two of these injuries were most likely caused by fishing gear and two others were most likely the result of a propeller hit. Further investigation on the impact of such fishing operations off northern and north-eastern Brazil on False killer whales and other smaller pelagic delphinids is highly needed.

The records of Bottlenose, Rough-toothed, and Common dolphins indicate their regular presence in neritic waters off northern Brazil, where then are referred by the fishermen as 'tuninas'. The Common dolphin specimen recorded at Praia da Pedra do Sal is certainly of special interest as so little is known of this population inhabiting the north-eastern coast (see Tavares et al. 2010 for more details).

The evidence of consumption of a fresh Fraser's dolphin denotes further investigation on the use of marine bushmeat along small fishing communities of north-eastern Brazil. Tosi et al. (2008) have reported a similar episode involving Fraser's dolphin consumption in the coast of Maranhão. Even if these represent fortuity events, dolphin and whale meat consumption should be more deeply investigated in such villages in future surveys.

Regarding coastal species, a mass stranding of Guiana dolphins was reported for the first time, based on an incident recorded in Salinópolis (EP), on January 2013. The coastline of Pará possesses certain unique features, such as very strong tides that cause accelerated movement of the sand banks and tidal channels. It seems plausible to believe in a natural condition characterized by this muddy beach and fast lowering tide acting as a trap. Although Guiana dolphins are familiar with flat waters and tide dynamism, the particular location of the Praia da Corvina could have acted as a natural trap. Nonetheless, the singularity of this event is worth mentioning and adds a new feature to the natural behavior of Guiana dolphins.

The cetacean fauna off the north and north-eastern Brazilian coast is much richer and diverse that previously thought, including both residents of tropical oligotrophic waters and highly-migrating baleen whales. Species associated to productive environments are also included, such as Bryde's whales and the Common dolphin. As pointed out by the present survey, the connection with the southern Caribbean cetacean fauna seems plausible and deserves further investigation. This is particularly relevant for understanding the affinity of north Brazilian Bryde's whale and Common dolphin populations with the adjacent Venezuela regional aggregations of these species (Galindo 
2007). There is a lack of information on countries of Wider Caribbean Region as Guyana, Suriname, and French Guiana, however, surveys developed at Guiana’s coastal province supply important records on cetacean composition (Manocci et al 2013, Boer 2015). Such a relationship is highly expected and could potentially connect the north Brazilian cetacean fauna with that from the southern Caribbean.

\section{Conclusions}

Strandings of uncommon cetacean species and a live beached Sperm whale are recorded for the first time along the north coast of Brazil. Balaenopterids records (Balaenoptera borealis and B. physalus) presented herein are of particular importance and include the very first of its category on the northern coast of Brazil providing new insights on migration movements on the southern hemisphere.

Evidence of anthropogenic injuries inflicted to cetaceans and also the consumption of marine bushmeat is reported to the north-eastern coast of Brazil. Although the proximity of the northern and the north-eastern Brazilian coasts, results showed that cetacean fauna in northern is more similar with the Caribbean region. Further investigation on movements and distribution patterns should be encouraged.

In this context, beach surveys and stranding network definitely provide relevant information on marine mammals' richness and diversity is this vast region. The cetacean fauna of north and north-eastern Brazil combines different elements from tropical marine ecosystems under the influence of the most powerful river of the world. Such dynamism requires a proportional research effort to better evaluate and understand its own complexity.

\section{Acknowledgments}

We would like to thank the GEMAM members who helped with field surveys, carcass collections, and processing at the Pará coast. AF Costa is indebted to Herbert Freitas (Quadrado) for his support and the collections made at the Piauí coast, without his help we would not have obtained the diversity of cetaceans in that sector. We are grateful to veterinarians Dr Valíria Cerqueira and Dr Pedro Bezerra and their staff from the Universidade Federal do Pará/Instituto de Medicina Veterinária-Campus Castanhal for their assistance in necropsies and staff of NUBIO/IBAMA/SUPES/PA for all the logistic and technical support for the stranding callings. Thanks to the staff of the MPEG, especially to the Setor de Mastozoologia for the support given to our research group along all these years.

This study was supported by VALE/FAPESPA/FAPEMIG (Process no. 038/2011) and Petrobras (Projeto Bicho D'água: Conservação Socioambiental and Projeto Cetáceos do Maranhão). M Sousa received a scholarship from Coordenação de Aperfeiçoamento de Pessoal de Nível Superior-CAPES. T Giarrizzo is funded by CAPES 
(PNPD), and receives a productivity grant from Conselho Nacional de Desenvolvimento Científico e Tecnológico-CNPq (310299/2016-0). This article is part of Alexandra Costa's $\mathrm{PhD}$ thesis in Aquatic Ecology and Fishery from the Universidade Federal do Pará. CAPES provided the scholarship for AF Costa during PhD course. Programa de Capacitação Institucional (MPEG/MCTI) provides a research grant to AFCosta (313522/2015-4) and REmin-Lima (313356/2015-7).

\section{References}

Alves-Junior TTA, Ávila FJ, Oliveira J, Furtado-Neto MAA, Monteiro-Neto C (1996) Registros de cetáceos para o litoral do Estado do Ceará, Brasil. Arquivos de Ciências do Mar 30: 79-92. http://setores.ufc.br/labomar/wp-content/uploads/2017/01/acm-1996-30-1-2-11.pdf

Authier M, Peltier H, Dorémus G, Dabin W, Van Canneyt O, Ridoux V (2014) How much are stranding records affected by variation in reporting rates? A case study of small delphinids in the Bay of Biscay. Biodiversity and Conservation 23: 2591-2612. https://doi. org/10.1007/s10531-014-0741-3

Best RB, Lockyer CH (2002) Reproduction, growth and migrations of sei whales Balaenoptera borealis off the West Coast of South Africa in the 1960s. South African Journal of Marine Science 24: 111-133. https://doi.org/10.2989/025776102784528510

Borowski GH (1781) Gemeinnüzzige[sic] Naturschichte des Tierreichs, G. L. Lange, Berlin and Stralsund, 2(1), $21 \mathrm{pp}$.

Byrd BL, Hohn AA, Lovewell GN, Altman KM, Barco SG, Friedlaender AS, Harms CA, McLellan WA, Moore KMT, Rosel PE, Thayer VG (2014) Strandings as indicators of marine mammal biodiversity and human interactions off the coast of North Carolina. Fishery Bulletin 112: 1-23. https://doi.org/10.7755/FB.112.1.1

Clarke K, Gorley R (2006) PRIMER User Manual/Tutorial. PRIMER-E, 192 pp.

Covelo P, Martínez-Cedeira J, Llavona Á, Díaz JI, López A (2015) Strandings of Beaked Whales (Ziphiidae) in Galicia (NW Spain) between 1990 and 2013. Journal of the Marine Biological Association of the United Kingdom 96: 1-7. https://doi.org/10.1017/ S002531541500048X

Cuvier [G] F (1812) Rapport fait à la classe des sciences mathematiques et physiques: sur divers cétacés pris sur les côtes de France, principalement sur ceux qui sont échonés près de Paimpol, le 7 janvier 1812. Annales du Muséum d'Histoire naturelle [Paris] vol 19: 13-14.

De Boer M (2015) Cetaceans observed in Suriname and adjacent waters. Latin American Journal of Aquatic Mammals 10: 2-19. https://doi.org/10.5597/lajam00189

DHN Departamento de Hidrografia e Navegaçấo (2010) Tábua de Marés. http://www.mar. mil.br/dhn/chm/tabuas/index.htm

Evans K, Thresher R, Warneke RM, Bradshaw CJA, Pook M, Thiele D, Hindell MA (2005) Periodic variability in cetacean strandings: links to large-scale climate events. Biology Letters 1: 147-50. https://doi.org/10.1098/rsbl.2005.0313

Fraser FC (1956) A new Sarawak dolphin. Sarawak Museum Journal, 7: 478-503. 
Galindo RA (2007) Potencial geographical distributions of seven species of marine cetaceans reported in Venezuela, Southeast Caribbean. Acta Zoologica Sinica 53: 853-864. http:// www.actazool.org/temp/\%7B9D76027C-D271-4580-88D1-4FCA189EE874\%7D.pdf

Geraci JR, Lounsbury VJ (1993) Marine Mammals Ashore - A field guide for strandings. Texas A\&M University Sea Grant College Program and the U.S, Ontario, 305 pp.

Gray J.E (1846) Zoology of the voyage of H.M.S. Erebus and Terror, 1 (Mammalia), 48 pp. Jung J-L, Mullié WC, Van Waerebeek K, Wagne MM, Ould Bilal AS, Ould Sidaty ZEA, Toomey L, Méheust E, Marret F (2015) Omura's whale off West Africa: autochthonous population or inter-oceanic vagrant in the Atlantic Ocean? Marine Biology Research 12: 66-75. https://doi.org/10.1080/17451000.2015.1084424

Lesson, R. P (1828) Histoire Naturelle, Générale et Particulière des Mammifères et des Oiseaux Découverts depuis 1788 jusqu'à nos Jours, Complément des oeuvres de Buffon, ou historie naturelle des animaux rares découverts par les naturalistes et les voyageurs depuis la mort de Buffon. Baudoin Frères, Paris.

Linnaeus C (1758) Systema Naturae per regna tria naturae, secundum classes, ordines, genera, species, cum characteribus, differentiis, synonymis, locis. Editio decima, reformata. Laurentius Salvius, Holmiae, 824 pp.

Lucena A (2006) Estrutura populacional da Balaenoptera bonaerensis (Burmeister) (Cetacea, Balaenopteridae) nas áreas de reprodução do Oceano Atlântico Sul. Revista Brasileira de Zoologia 23: 176-185. https://doi.org/10.1590/S0101-81752006000100009

Luksenburg J (2014a) Prevalence of external injuries in small cetaceans in aruban waters, Southern Caribbean. PLoS ONE 9: 1-10. https://doi.org/10.1371/journal.pone.0088988

Luksenburg J (2014b) The cetaceans of Aruba, southern Caribbean. Journal of the Marine Biological Association of the United Kingdom 94: 1161-1174. https://doi.org/10.1017/ S0025315413000337

Magalhães FA, Tosi CH, Garri RG, Chellappa S, Silva FL (2008) Cetacean diversity on the Parnaíba Delta, Maranhão state, northeastern Brazil. Brazilian Journal of Biology 68: 545-551. https:// doi.org/10.1590/S1519-69842008000300012

Maldini D, Mazzuca L, Atkinson S (2005) Odontocete Stranding Patterns in the Main Hawaiian Islands (1937-2002): How Do They Compare with Live Animal Surveys? Pacific Science 59: 55-67. https://doi.org/10.1353/psc.2005.0009

Mannocci L, Monestiez P, Bolańos-Jiménez J, Dorémus G, Jeremie S, Laran S, Rinaldi R, Van Canneyt O, Ridoux V (2013) Megavertebrate communities from two contrasting ecosystems in the western tropical Atlantic. Journal of Marine Systems 111-112: 208-222. https://doi.org/10.1016/j.jmarsys.2012.11.002

Meirelles ACO, Monteiro-Neto C, Martins AMA, Costa AF, Barros HMDR, Alves MDO (2009) Cetacean strandings on the coast of Ceará, north-eastern Brazil (1992-2005). Journal of the Marine Biological Association of the United Kingdom 89: 1-8. https://doi. org/10.1017/S0025315409002215

Moraes BC, Costa JMN, Costa ACL, Costa MH (2005) Variação espacial e temporal da precipitação no estado do Pará. Acta Amazonica 35: 207-214. https://doi.org/10.1590/S004459672005000200010

Montagu G (1821) Description of a species of Delphinus, which appears to be new. Memoirs of the Wernerian Natural History Society 3: 75-82. 
Moreira AM, Mavigner DS (2007) Conhecendo história e geografia do Piauí. 1a Edição. Gráfica Ferraz, Parnaíba, 184 pp.

Motta MRA, Pinheiro DCSN, Carvalho VL, Viana DDA, Vicente ACP, Iñiguez AM (2008) Gastric lesions associated with the presence of Anisakis spp. Dujardin, 1845 (Nematoda: Anisakidae) in Cetaceans stranded on the coast of Ceara, Brazil. Biota Neotropica 8: 9195. https://doi.org/10.1590/S1676-06032008000200010

Moura JF, Siciliano S (2012) Stranding pattern of Bryde's whales along the south-eastern coast of Brazil. Marine Biodiversity Records 5: 1-7. https://doi.org/10.1017/S1755267212000528 Moura RL, Amado-Filho GM, Moraes FC, Brasileiro PS, Salomon PS, Mahiques MM, Bastos AC, Almeida MG, Silva Jr JM, Araujo BF, Brito FP, Rangel TP, Oliveira BCV, Bahia RG, Paranhos RP, Dias RJS, Siegle E, Figueiredo Jr AG, Pereira RC, Leal CV, Hajdu E, Asp NE, Gregoracci GB, Neumann-Leitão S, Yager PL, Francini-Filho RB, Fróes A, Campeão M, Silva BS, Moreira APB, Oliveira L, Soares AC, Araujo L, Oliveira NL, Teixeira JB, Valle RAB, Thompson CC, Rezende CE, Thompson FL (2016) An extensive reef system at the Amazon River mouth. Science Advances 1-11. https://doi.org/10.1126/ sciadv. 1501252

Norman SA, Bowlby CE, Brancato MS, Calambokidis J, Duffield D, Gearin PJ (2004) Cetacean strandings in Oregon and Washington between 1930 and 2002. Journal of Cetacean Research Management 6: 87-99.

Owen R (1846) A history of British fossil mammals, and birds. Illustrated by 237 woodcuts. J. Van Voorst, London, 516 pp. https://doi.org/10.5962/bhl.title.13248

Peltier H, Dabin W, Daniel P, Van Canneyt O, Dorémus G, Huon M, Ridoux V (2012) The significance of stranding data as indicators of cetacean populations at sea: Modelling the drift of cetacean carcasses. Ecological Indicators 18: 278-290. https://doi.org/10.1016/j. ecolind.2011.11.014

Pinedo MC, Lammardo MP, Barreto AS (2001) Review of Ziphius cavirostris, Mesoplodon grayi and Lagenodelphis hosei (Cetacea: Ziphiidae and Delphinidae) in Brazilian waters, with new records from southern Brazil. Atlântica 23: 67-76.

Prado JHF, Mattos PH, Silva KG, Secchi ER (2016) Long-term seasonal and interannual patterns of marine mammal strandings in subtropical western South Atlantic. PLoS ONE 11: 1-23. https://doi.org/10.1371/journal.pone.0146339

Pyenson ND (2010) Carcasses on the coastline: measuring the ecological fidelity of the cetacean stranding record in the eastern North Pacific Ocean. Paleobiology 36: 453-480. https://doi.org/10.1666/09018.1

Ramos RMA, Siciliano S, Ribeiro R (2010) Monitoramento da biota marinha em navios de sísmica: seis anos de pesquisa (2001-2007). Everest Tecnologia em Serviços, Vitória, ES, $1200 \mathrm{pp}$.

Romero A, Creswell J (2005) In the Land of the mermaid: How culture, not ecology, influenced marine mammal exploitation in the Southeastern Caribbean. In: Romero A, West $S$ (Eds) Environmental Issues in Latin America and the Caribbean. Springer, New York, 3-30. https://doi.org/10.1007/1-4020-3774-1

Santos MCO, Siciliano S, Vicente AFC, Siqueira FA, Zampirolli É, de Souza SP, Maranho A (2010) Cetacean records along São Paulo state coast, Southeastern Brazil. Brazilian Journal of Oceanography 58: 123-142. https://doi.org/10.1590/S1679-87592010000200004 
Siciliano S, Emin-lima NR, Costa AF, Tosi CH, Garri RG, Regina C, Silva DA, Sousa JDE, Júnior ES (2008) Revisão do Conhecimento sobre os Mamíferos Aquáticos da Costa Norte do Brasil. Arquivos do Museu Nacional 66: 381-401.

Siciliano S, Moura JF, Emin-Lima R, Arcoverde DL, Sousa MEM, Martins BML, Silva-Jr J de S, Tavares M, Santos MCO, Ott PH (2011) Large baleen whales on the coast of Brazil: a review of post-1997 data on strandings and sightings. IWC Scientific Committee 63: 1-12.

Souza-Filho PWM, Gonçalves F, Beisl CH, Miranda FP, Almeida EF, Cunha ER (2005) Sistema de Observação Costeira e o Papel dos Sensores Remotos no Monitoramento da Costa Norte Brasileira, Amazônia. Revista Brasileira de Cartografia 2: 79-86. http://lsie.unb.br/index. $\mathrm{php} / \mathrm{rbc} /$ article/download/135/118

Souza-Filho PWM (2005) Costa de Manguezais de Macromaré da Amazônia: Cenários Morfológicos, Mapeamento e Quantificação de Áreas usando Dados de Sensores Remotos. Journal of Chemical Information and Modeling 23: 427-435. https://doi.org/10.1017/ CBO9781107415324.004

Souza-Filho PWM, Lessa GC, Cohen MCL, Costa FR, Lara RJ (2008) The Subsiding Macrotidal Barrier Estuarine System of the Eastern Amazon Coast, Northern Brazil. In: Dillenburg, Sérgio F., Hesp PA (Ed.) Geology of Brazilian Coastal Barriers. Springer-Verlag, New York, 1-29. https://doi.org/10.1007/978-3-540-44771-9

Szczygielski A, Stattegger K, Schwarzer K, da Silva AGA, Vital H, Koenig J (2014) Evolution of the Parnaíba Delta (NE Brazil) during the late Holocene. Geo-Marine Letters 35: 105-117. https://doi.org/10.1007/s00367-014-0395-x

Tavares M, Moreno IB, Siciliano S, Rodriguez D, Marcos MC, Lailson-Brito J, Fabián ME (2010) Biogeography of common dolphins (genus Delphinus) in the southwestern Atlantic Ocean. Mammal Review 40: 40-64. https://doi.org/10.1111/j.1365-2907.2009.00154.x Toledo G, Langguth A (2009) Data on biology and exploitation of West Atlantic sperm whales, Physeter macrocephalus (Cetacea: Physeteridae) off the coast of Paraíba, Brazil. Zoologia (Curitiba, Impresso) 26: 663-673. https://doi.org/10.1590/S1984-46702009000400011

Tosi CH, Garri RG, Magalhães FA (2006) Encalhes de cachalote (Physeter macrocephalus) (Linnaeus, 1758) no Estado do Maranhão - Brasil. In: 1a Reunión Internacional sobre el Estudio de los Mamíferos Acuáticos SOMEMMA - SOLAMAC. Universidad Autónoma de Yucatán, Merida, $101 \mathrm{pp}$.

Tosi CH, Magalhães AF, Garri RG (2008) Meat Consumption of a Fraser's Dolphin (Lagenodelphis hosei) Stranded Alive in the Northern Brazilian Coast. Journal of the Marine Biodiversity Records of the United Kingdom 2: e4. https://doi.org/10.1017/S1755267208000043

Van Beneden, P. J (1864) Mém. Cour. Acad. Roy, Bruxelles, Coll., 16(2): 27. [fig. 31-34, pl. 2] Whitehead H (2009) Sperm whale. In: Perrin WF, Wursig B, Thewissen J (Eds) Encyclopedia of Marine Mammals. Elsevier, 1091-1097. https://doi.org/10.1016/b978-0-12-3735539.00248-0

Zerbini AN, Secchi ER, Bassoi M, Dalla Rosa L, Higa A, Sousa L, Moreno IB, Moller LM, Caon G (2004) Série documentos revizee - score sul distribuição e abundância relativa de cetáceos na Zona Econômica Exclusiva da Região Sudeste-Sul do Brasil. Instituto Oceanográfico, São Paulo, 1-40. http://www.mma.gov.br/estruturas/revizee/_arquivos/revizee_ cetaceos.pdf 


\section{Supplementary material I}

\section{S1 Movie}

Authors: Alexandra Fernandes Costa, Salvatore Siciliano, Renata Emin-Lima, Bruna Maria Lima Martins, Maura Elisabeth Moraes Sousa, Tommaso Giarrizzo, José de Sousa e Silva Júnior

Data type: MOV file

Explanation note: Dolphins trapped at Praia da Corvina, Salinópolis (MOV).

Copyright notice: This dataset is made available under the Open Database License (http://opendatacommons.org/licenses/odbl/1.0/). The Open Database License $(\mathrm{ODbL})$ is a license agreement intended to allow users to freely share, modify, and use this Dataset while maintaining this same freedom for others, provided that the original source and author(s) are credited.

Link: https://doi.org/10.3897/zookeys.688.12636.suppl1

\section{Supplementary material 2}

\section{S2 Movie}

Authors: Alexandra Fernandes Costa, Salvatore Siciliano, Renata Emin-Lima, Bruna Maria Lima Martins, Maura Elisabeth Moraes Sousa, Tommaso Giarrizzo, José de Sousa e Silva Júnior

Data type: MOV file

Explanation note: Rescue Guiana dolphins trapped at Praia da Corvina, Salinópolis (MOV).

Copyright notice: This dataset is made available under the Open Database License (http://opendatacommons.org/licenses/odbl/1.0/). The Open Database License $(\mathrm{ODbL})$ is a license agreement intended to allow users to freely share, modify, and use this Dataset while maintaining this same freedom for others, provided that the original source and author(s) are credited.

Link: https://doi.org/10.3897/zookeys.688.12636.suppl2 


\section{Supplementary material 3}

\section{S3 Movie}

Authors: north-eastern Brazilian coasts

Alexandra Fernandes Costa, Salvatore Siciliano, Renata Emin-Lima, Bruna Maria Lima Martins, Maura Elisabeth Moraes Sousa, Tommaso Giarrizzo, José de Sousa e Silva Júnior

Data type: MOV file

Explanation note: Dolphin stranded at Praia da Travosa, Santo Amaro (MOV)

Copyright notice: This dataset is made available under the Open Database License (http://opendatacommons.org/licenses/odbl/1.0/). The Open Database License $(\mathrm{ODbL})$ is a license agreement intended to allow users to freely share, modify, and use this Dataset while maintaining this same freedom for others, provided that the original source and author(s) are credited.

Link: https://doi.org/10.3897/zookeys.688.12636.suppl3 